\title{
A Long-term Follow-up Study of Japanese Diabetic Patients: Mortality and Causes of Death
}

\author{
A. Sasaki, M. Uehara, N. Horiuchi and K. Hasagawa \\ Centre for Adult Diseases, Osaka, Osaka, Japan
}

Summary. A systematic 20-year follow-up study of 1,221 diabetic patients was carried out in Osaka, Japan. The mean annual mortality rates were $2.55 \%$ for men and $1.64 \%$ for women. The ratios of observed to expected numbers of deaths were 1.50 for men and 1.39 for women, indicating an excess mortality for diabetic patients of both sexes, and higher mortality in men than in women. Factors that predisposed diabetic patients to premature death were early age of onset, albuminuria, diabetic retinopathy and fasting glucose level $>11.1 \mathrm{mmol} / 1$ at the initial examination. Insulin dependence was also associated with poor prognosis. Cerebro-cardiovascular and renal diseases were the major causes of death in the diabetic patients; heart disease was the cause of death in $16.9 \%$, cerebrovascular disease in $16.4 \%$ and renal disease in $11.9 \%$. The relatively high incidence of renal disease as cause of death in diabetic patients was striking. Malignant neoplasms of liver and of pancreas and cirrhosis were also associated with increased ratio of observed to expected number of deaths in the patients.

Key words: Prognosis of diabetic patients, long-term followup, excess mortality, causes of death, vascular complications, Japan.
Studies on diabetic patients in Western countries have consistently shown a poor prognosis compared with the life expectancy of the general population [1-9]. This is due largely to late manifestation of cardiovascular complications of the disease [5-8]. Some previous studies suggest that there may be differences between diabetic patients in Japan and those in the West with regard to clinical manifestation and complications of the disease and causes of death [10-12]. However, detailed information is lacking on long-term prognosis in Japan. A long-term follow-up study of diabetic patients was started at our hospital in Osaka in 1962. The present report concerns the mortality rates and causes of death in our patients during the past 20 years.

\section{Subjects and Methods}

\section{Patients}

A total of 1,221 diabetic patients ( 705 men and 516 women) first seen at our hospital during the period 1962-1979 were studied. They were all Type 2 (non-insulin-dependent) diabetic patients, newly diagnosed $(70.9 \%)$ or with duration of disease $<5$ years at entry to the study $(29.1 \%)$. They had fasting glucose level $\geqslant 6.7 \mathrm{mmol} / 1(120 \mathrm{mg} / \mathrm{dl})$ and $/$ or $2 \mathrm{~h}$ glucose level $\geqslant 10.0 \mathrm{mmol} / 1(180 \mathrm{mg} / \mathrm{dl})$ in their first $50 \mathrm{~g}$ oral glucose tolerance test, in which venous blood samples were taken and plasma glucose determined by the ferricyanide method on a Technicon autoanalyzer. The mean \pm SEM age of the subjects at entry to the study was $50.5 \pm 0.4$ years for men and $54.0 \pm 0.5$ years for women (Table 1). All subjects were followed up to the end of 1981; the mean follow-up period was 7.5 years for both sexes.

\section{Methods}

The patients were followed up by hospital outpatient computer, questionnaire, community record, or by a direct telephone call when all else failed, and their vital states (alive or dead) were confirmed. Since 1978 , these procedures have been repeated yearly.

For each subject confirmed dead, a copy of the death certificate was obtained and the causes of death determined from both medical record and death certificate. The causes of death were classified according to the eighth revision of the International Classification of Diseases.

Since the period of observation varies with individual patients, a mean mortality rate was computed on a person-year basis by dividing number of deaths by sum of individual follow-up years in each sex. and age group. The mortality in diabetic patients was compared with that in the general population in Osaka by computing a ratio of observed to expected number of deaths $(\mathrm{O} / \mathrm{E}$ ratio). The expected number of deaths was estimated using mortality statistics from the Osaka Prefecture during the follow-up period on the yearly basis. The statistical significance of $\mathrm{O} / \mathrm{E}$ ratios and their association with risk factors were calculated using a $\chi^{2}$ test.

Obesity was defined as body weight above $115 \%$ of the ideal body weight, using the standard weight and height tables for Japanese [13]. Urine protein was determined by Albustix (Miles-Sankyo Company, 
Table 1. Number of patients studied and mean annual mortality rates by sex and age at entry to the study

\begin{tabular}{|c|c|c|c|c|}
\hline \multirow{2}{*}{$\begin{array}{l}\text { Age at } \\
\text { entry } \\
\text { (years) }\end{array}$} & \multicolumn{2}{|l|}{ Males } & \multicolumn{2}{|l|}{ Females } \\
\hline & $\begin{array}{l}\text { No. of } \\
\text { patients }\end{array}$ & $\begin{array}{l}\text { Annual } \\
\text { mortality } \\
\text { rate }(\%)^{\mathrm{a}}\end{array}$ & $\begin{array}{l}\text { No. of } \\
\text { patients }\end{array}$ & $\begin{array}{l}\text { Annual } \\
\text { mortality } \\
\text { rate }(\%)^{a}\end{array}$ \\
\hline$<35$ & 52 & 0.92 & 16 & 3.85 \\
\hline $35-44$ & 185 & 0.97 & 80 & 0.68 \\
\hline $45-54$ & 209 & 1.92 & 169 & 0.86 \\
\hline $55-64$ & 166 & 3.90 & 175 & 2.19 \\
\hline $65+$ & 93 & 6.59 & 76 & 3.17 \\
\hline Total & 705 & 2.55 & 516 & 1.64 \\
\hline Mean age & \multicolumn{2}{|c|}{$50.45 \pm 0.44$} & \multicolumn{2}{|c|}{$54.02 \pm 0.46$} \\
\hline
\end{tabular}

Expressed as mean age $\pm S E M$. ${ }^{\text {a }}$ Indicates mean annual mortality rate computed on the person-year basis during the follow-up period

Table 2. Observed and expected numbers of deaths and $\mathrm{O} / \mathrm{E}$ ratios during follow-up period by sex and age at entry to the study

\begin{tabular}{|c|c|c|c|c|c|c|}
\hline \multirow{2}{*}{$\begin{array}{l}\text { Age at } \\
\text { entry } \\
\text { (years) }\end{array}$} & \multicolumn{3}{|c|}{ Males } & \multicolumn{3}{|c|}{ Females } \\
\hline & Obs & Exp & $\mathrm{O} / \mathrm{E}$ & Obs & Exp & $\mathrm{O} / \mathrm{E}$ \\
\hline $\left.\begin{array}{r}<35 \\
35-44\end{array}\right\}$ & 19 & 2.83 & $6.71^{\mathrm{b}}$ & 9 & 0.60 & $15.00^{\mathrm{a}}$ \\
\hline $45-54$ & 30 & 9.74 & $3.08^{b}$ & 11 & 3.88 & 2.84 \\
\hline $55-64$ & 47 & 20.82 & $2.26^{\mathrm{b}}$ & 28 & 10.46 & $2.68^{b}$ \\
\hline $65+$ & 41 & 57.77 & $0.71^{\mathrm{a}}$ & 16 & 31.12 & $0.51^{\mathrm{a}}$ \\
\hline Total & 137 & 91.17 & $1.50^{\mathrm{b}}$ & 64 & 46.06 & 1.39 \\
\hline
\end{tabular}

Obs = observed number of deaths; $\operatorname{Exp}=$ expected number of deaths; $\mathrm{O} / \mathrm{E}=$ ratio of observed to expected number of deaths. ${ }^{\mathrm{a}} p<0.05$, ${ }^{\mathrm{b}} p<0.01$

Tokyo, Japan) and $(+)$ or more was defined as positive albuminuria. Impaired renal function was defined as phenolsulfonephthalein excretion (in the PSP-test) below $25 \%$ at $15 \mathrm{~min}$.

\section{Results}

\section{Mortality}

At the end of 1981, 1,019 patients were alive, 201 were dead and one could not be traced. Mean annual mortality rates were $2.55 \%$ for men and $1.64 \%$ for women, with a sharply increasing trend with age for both sexes (Table 1). Observed and expected numbers of deaths and $\mathrm{O} / \mathrm{E}$ ratios are given in Table 2. $\mathrm{O} / \mathrm{E}$ ratios were 1.50 for diabetic men and 1.39 for diabetic women, both of which indicated higher mortality in diabetic patients than in the general population in Osaka. $\mathrm{O} / \mathrm{E}$ ratios were inversely related to age at entry to the study, revealing significant excess mortality in the patients with younger ages, but no excess mortality in the patients older than 65 years.

\section{Factors Related to Excess Mortality in Diabetic Patients}

$\mathrm{O} / \mathrm{E}$ ratios were further analyzed in relation to other factors that might affect the prognosis (Fig.1). Age at

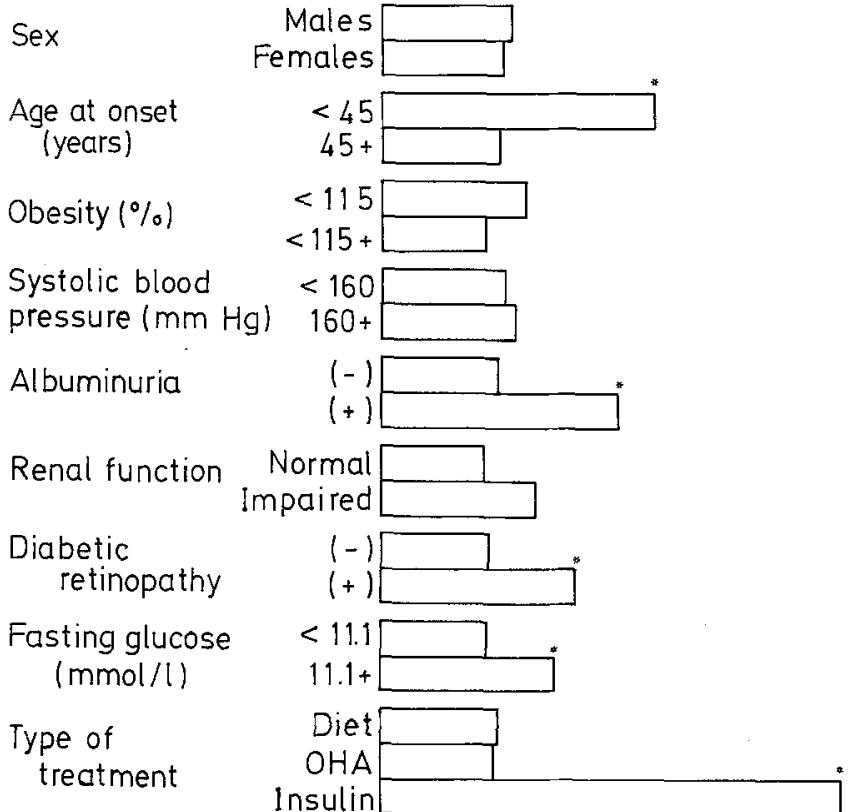

Fig.1. Ratios of observed to expected number of deaths (O/E ratios) in relation to various factors in 1,220 Japanese diabetic patients. The $\mathrm{O} / \mathrm{E}$ ratios were computed using mortality statistics from Osaka Prefecture during the follow-up period. OHA = oral hypoglycaemic agent, $* p<0.05$

onset of diabetes $<45$ years, albuminuria, diabetic retinopathy, fasting glucose level $>11.1 \mathrm{mmol} / 1$, and insulin treatment were associated with $\mathrm{O} / \mathrm{E}$ ratios significantly higher than in patients without these conditions. Obesity and impaired renal function also tended to influence the $\mathrm{O} / \mathrm{E}$ ratios but without reaching statistical significante.

The reason for the higher mortality in the insulintreated group was analyzed by examining the frequency of the above-stated risk factors in that group. In general, patients treated with insulin tended to have an earlier age of onset of diabetes, less obesity and higher fasting glucose levels than patients given other types of treatment.

\section{Causes of Death}

Cerebro-cardiovascular and renal disease were the major causes of death, accounting for nearly half (45.8\%, Table 3 ). Among them, heart disease was the cause of death in $16.9 \%$ of patients, cerebrovascular disease in $16.4 \%$ and renal disease (including diabetic nephropathy) in $11.9 \%$. More than a quarter of the deaths $(26.9 \%)$ were attributed to malignant neoplasms, with cancer of the liver most frequent.

The $\mathrm{O} / \mathrm{E}$ ratio for renal disease (11.82) was remarkably high in diabetic patients. $\mathrm{O} / \mathrm{E}$ ratios were also high for ischaemic heart disease (2.31), and hypertensive heart disease (1.93). On the other hand, cerebrovascular 
Table 3. Observed and expected numbers of deaths and $\mathrm{O} / \mathrm{E}$ ratios by specified causes

\begin{tabular}{lrrr}
\hline $\begin{array}{l}\text { Causes of deaths } \\
\text { (8th Revision of International }\end{array}$ & $\begin{array}{l}\text { No. of } \\
\text { deaths } \\
\text { observed }\end{array}$ & $\begin{array}{l}\text { No. of } \\
\text { deaths } \\
\text { expected }\end{array}$ & $\begin{array}{c}\text { O/E } \\
\text { ratio }\end{array}$ \\
\hline All causes & 201 & 137.22 & 1.46 \\
Diabetes & 4 & 2.35 & 1.70 \\
Malignant neoplasms & 54 & 38.17 & 1.41 \\
$\quad$ All sites & 10 & 13.14 & 0.76 \\
$\quad$ Stomach & 19 & 2.19 & $6.22^{\mathrm{b}}$ \\
$\quad$ Liver & 4 & 1.48 & 2.70 \\
$\quad$ Pancreas & 7 & 5.50 & 1.27 \\
$\quad$ Lung & 92 & 56.79 & $1.62^{\mathrm{b}}$ \\
Cerebro-cardiovascular & 34 & 24.17 & 1.44 \\
$\quad$ and renal disease & 5 & 2.59 & 1.93 \\
$\quad$ Disease of heart & 21 & 9.08 & $2.31^{\mathrm{a}}$ \\
$\quad$ Hypertensive heart disease & 33 & 28.61 & 1.15 \\
$\quad$ Ischaemic heart disease & 24 & 2.03 & $11.82^{\mathrm{b}}$ \\
$\quad$ Cerebrovascular disease & 5 & 5.62 & 0.89 \\
$\quad$ Renal disease & 18 & 5.56 & $3.24^{\mathrm{a}}$ \\
Pneumonia and bronchitis & 28 & 28.73 & 0.97 \\
Cirrhosis & & & \\
Other causes & &
\end{tabular}

$\mathrm{O} / \mathrm{E}=$ ratio of observed to expected number of deaths. a $p<0.05$, b $p<0.01$

disease showed only a slight increase compared with the general population. Malignant neoplasms also showed an increase in $\mathrm{O} / \mathrm{E}$ ratios, particularly for cancer of liver (8.86), and of pancreas (2.70). In addition, the $\mathrm{O} / \mathrm{E}$ ratio for cirrhosis was increased in diabetic patients (3.24).

Subsequent analysis showed a sex difference in renal disease, with a higher frequency in women than in men. In contrast, no sex differences in cerebrovascular and heart disease as cause of death were noted among the patients.

\section{Discussion}

Studies in the West consistently show diabetic patients to have a higher mortality and a shorter life expectancy than the general population. Kessler [5] found standardized mortality ratios of 1.74 for men and 1.27 for women at the Joslin Clinic, and Królewski et al. [6] reported $\mathrm{O} / \mathrm{E}$ ratios of 1.31 for men and 1.27 for women in diabetic patients in Warsaw. An excessive mortality of diabetic patients was also observed in the district of Erfurt, Germany [4], while the mortality rate of male diabetic patients was found to be increased by a factor of 2.62 in a 10-year study on employees at the Du Pont Company [8]. Similarly, a survey in Birmingham, UK, indicated mortality in diabetic patients to be 1.37 times higher than in the general population [9].

The present study was carried out to obtain detailed information on the prognosis of diabetic patients in Japan. The $\mathrm{O} / \mathrm{E}$ ratios found in our male and female patients correspond to most of those found in studies car- ried out in the West $[5,7,8]$. In our study, a higher mortality was found in diabetic men than in diabetic women, which agrees with some $[4,5]$, but not other studies from Western countries [1, 5, 7, 14].

The present findings indicate that albuminuria, diabetic retinopathy, a fasting glucose level $>11.1 \mathrm{mmol} / 1$ and early onset of the disease tended to increase the mortality of Japanese diabetic patients. Thus, the present study agrees largely with a previous epidemiological study of Japanese diabetic patients which showed that the degree of glucose intolerance, hypertension, ischaemic changes on the electrocardiogram and albuminuria were associated with poor prognosis [11]. It is noteworthy that similar risk factors for mortality in diabetic patients were reported by Gottlieb in a study at the Joslin Clinic [15] and by Pell and D'Alonzo at the Du Pont Company [8].

Cerebro-cardiovascular and renal diseases, or angiopathy, were the major causes of death in the present study; they accounted for nearly half the deaths and caused 1.62 times as many deaths as would be expected on the basis of mortality statistics from Osaka. The high frequency of cerebro-cardiovascular and renal diseases as causes of death in diabetes was also noted in two previous Japanese reports [12, 16], and resembles closely findings obtained in studies on diabetic patients in the West $[4,6,8,14]$. However, the frequency of three major angiopathies in our study somewhat differs from that in the West. The frequency of heart disease was much lower, while that of cerebrovascular and renal diseases was higher compared with the report from the Joslin Clinic [14]. Almost similar results on Japanese diabetic patients were reported previously $[16,17]$.

In addition, cancer of liver and of pancreas showed a marked increase as cause of death in diabetic patients compared with the general population. Cirrhosis also appeared to be a frequent cause of death in Japanese patients $[11,12]$, whereas it is rarely reported as a cause of death in diabetes in the West $[5,18,19]$. Nevertheless, the present findings suggest that the prognosis and causes of death in diabetic patients in Japan are in general similar to those in Western countries, except for some differences pointed out above.

\section{References}

1. Marks HH (1965) Longevity and mortality of diabetics. Am J Publ Hlth 55: 416-423

2. Hirohata T, MacMahon B, Root HF (1967) The natural history of diabetes. I. Mortality. Diabetes 16:875-881

3. Bale GS, Entmacher PS (1977) Estimated life expectancy of diabetics. Diabetes 13: 373-377

4. Panzram G, Zabel-Langhennig R (1981) Prognosis of diabetes mellitus in a geographically defined population. Diabetologia 20 : $587-591$

5. Kessler I (1971) Mortality experience of diabetic patients. A twenty-six year follow-up study. Amer J Med 51: 715-724 
6. Królewski AS, Czyzyk A, Janeczko D, Kopczynski J (1977) Mortality from cardiovascular disease among diabetics. Diabetologia 13: $345-350$

7. Garcia MJ, McNamara PM, Gordon T, Kannel WB (1974) Morbidity and mortality in diabetics in the Framingham population. Sixteen year follow-up study. Diabetes 23: 105-111

8. Pell S, D'Alonzo CA (1970) Factors associated with long-term survival of diabetics. JAMA 214: 1833-1840

9. Birmingham Diabetes Survey Working Party (1976) Ten-year follow-up report on Birmingham Diabetes Survey of 1961. Brit Med J 2: $35-37$

10. Blackard WG, Omori Y, Freeman LR (1965) Epidemiology of diabetes mellitus in Japan. J Chron Dis 18: 415-427

11. Sasaki A, Suzuki T, Horiuchi N (1980) Survival rates and causes of death of diabetics in Japan. A 10-year follow-up study. J Chron Dis $33: 341-346$

12. Sasaki A, Kamado K, Horiuchi N (1978) A changing pattern of causes of death in Japanese diabetics. Observation over fifteen years. J Chron Dis 31: 433-444

13. Minowa S, Takahashi S, Mayuzumi N, Miyashita H(1962) Studies on the standard body weight for Japanese adults. Jpn Med J No 1988: $24-30$

14. Marks HH, Krall LP (1971) Onset, course, prognosis and mortality in diabetes mellitus. In: Marble A, White P, Bradly RF, Krall LP (eds) Joslin's diabetes mellitus. 11th ed, Lea \& Febiger, Philadelphia, pp 209-254

15. Gottlieb MS (1974) The natural history of diabetes: factors present at time of diagnosis which may be predictive of lenth of survival. $J$ Chron Dis 27: 435-445

16. Hirata Y, Mihara T (1976) Principal causes of death among diabetic patients in Japan from 1968-1970. In: Baba S, Goto Y, Fukui I (eds) Diabetes mellitus in Asia. International Congress Series No 221. Exerpta Medica, Amsterdam, pp91-97

17. Mihara T, Ohashi H, Hirata Y (1982) A prospective study of 1,692 diabetics in Tokyo. In: Melish JS, Hanna J, Baba S (eds) Genetic environmental interaction in diabetes mellitus. International Congress Series No 549. Excerpta Medica, Amsterdam, pp 107-111

18. US Department of Health, Education and Welfare (1971) Diabetes mellitus in the United States 1950-1967. Public Health Publication No 1000-Series 20, No 10

19. Tokuhata GK, Miller W, Digon S, Hartman T (1975) Diabetes mellitus: an underestimated public health problem. J Chron Dis 28: $23-35$

Received: 25 November 1982

and in revised form: 24 April 1983

Dr. Akira Sasaki

Centre for Adult Diseases, Osaka

3 Nakamichi 1-chome

Higashinari-ku

Osaka 537

Japan 